\title{
FOREIGN DIRECT INVESTMENTS, TRADE OPENNESS AND CO2 EMISSIONS RELATIONSHIP: THE CASE OF 1995-2019 EU COUNTRIES
}

\author{
INVERSIONES EXTRANJERAS DIRECTAS, APERTURA COMERCIAL Y \\ RELACIÓN DE EMISIONES DE CO2: EL CASO DE LOS PAÍSES DE LA EU 1995- \\ 2019
}

\author{
${\text { Ahmet } \text { Kamaci }^{1} * \text { (iD) ; Ekrem Gul }}^{2}$ (D) ; Mustafa Torusdag ${ }^{3}$ (iD) . \\ 1. Bartin University, Faculty of Economics and Administrative Sciences, Department of Economics, Turkey. \\ akamaci@bartin.edu.tr. \\ 2. Sakarya University, Faculty of Political Economy, Department of Economy, Turkey. egul@sakarya.edu.tr. \\ 3. Van Yuzuncu Yil University, Faculty of Economics and Administrative Sciences, Department of Economics, Turkey. \\ mustafatorusdag@yyu.edu.tr. \\ *Corresponding author: Ahmet Kamaci, correo electrónico: akamaci@bartin.edu.tr
}

\begin{abstract}
Foreign Direct Investments (FDI), which are very important in the economic development of countries, prefer regions with free trade. Since the share of international trade in the world economy is constantly increasing, trade openness and foreign direct investments have become more important for countries. However, the increase in trade and FDI entries can have negative effects on the environment. Although many different variables are included in the literature as determinants of carbon emission, foreign direct investments are mostly taken as an explanatory variable with the effect of the economic globalization process.

The aim of this paper is to analyze the relationship between FDI, trade openness and CO2 emission for the 1995-2019 period in 24 EU countries. The relationship between variables was estimated by applying panel AMG estimator and Emirmahmutoglu and Kose causality tests to series with cross-sectional dependency. Empirical results for the overall panel show that there is unidirectional causality from carbon emission to trade openness and FDI. There is a directional causality from FDI to trade openness for the general panel has been determined. When analyzed on a country basis, there is unidirectional causality from carbon emission to trade openness for Bulgaria, Italy, Latvia, Poland, Portugal and Slovenia. Likewise, for Austria, Denmark, Estonia, Finland, France, Germany, Poland, Portugal, Spain and Switzerland, there is unidirectional causality from carbon emission to FDI. In addition, when analyzed on a country basis, there is a one-way causality relationship from foreign direct investments to trade openness for Bulgaria, Italia, Latvia, Poland, Portugal and Slovenia. For Bulgaria, Finland and Germany, there is a one-way causality from trade openness to foreign direct investment. The importance of this study derives from the emphasis on the need for environmentally protective FDIs to reduce carbon emissions.
\end{abstract}

Keywords: Carbon emission; foreign direct investment (FDI); trade openness; environmental Kuznets curve; pollution haven hypothesis; halo effect.

Cómo citar:

Kamaci , Ahmet; Gul, Ekrem; Torusdag, Mustafa. (2021). Foreign direct investments, trade openness and CO2 emissions relationship: the case of 1995-2019 eu countries. Revista de Investigaciones Universidad del Quindio, 33(2), 56-73. https://doi.org/10.33975/riuq.vol33n2.637 


\section{RESUMEN}

Las Inversiones Extranjeras Directas (IED), que son muy importantes en el desarrollo económico de los países, prefieren regiones con libre comercio. Dado que la participación del comercio internacional en la economía mundial aumenta constantemente, la apertura comercial y las inversiones extranjeras directas se han vuelto más importantes para los países. Sin embargo, el aumento del comercio y las entradas de IED pueden tener efectos negativos sobre el medio ambiente. Aunque en la literatura se incluyen muchas variables diferentes como determinantes de la emisión de carbono, la Inversión Extranjera Directa se toma principalmente como una variable explicativa del efecto del proceso de globalización económica.

El objetivo de este trabajo es analizar la relación entre la IED, la apertura comercial y la emisión de CO2 para el período 1995-2019 en 24 países de la EU. La relación entre variables se estimó aplicando el estimador de panel AMG y las pruebas de causalidad de Emirmahmutoglu y Kose a series con dependencia transversal. Los resultados empíricos del panel general muestran que existe una causalidad unidireccional entre la emisión de carbono y la apertura comercial y la IED. Se ha determinado una causalidad direccional de la IED a la apertura comercial para el panel general.

Cuando se analiza por país, existe una causalidad unidireccional de la emisión de carbono a la apertura comercial para Bulgaria, Italia, Letonia, Polonia, Portugal y Eslovenia. Asimismo, para Austria, Dinamarca, Estonia, Finlandia, Francia, Alemania, Polonia, Portugal, España y Suiza, existe una causalidad unidireccional de la emisión de carbono a la IED. Además, cuando se analiza por países, existe una relación de causalidad unidireccional entre las inversiones extranjeras directas y la apertura comercial para Bulgaria, Italia, Letonia, Polonia, Portugal y Eslovenia. Para Bulgaria, Finlandia y Alemania, existe una causalidad unidireccional entre la apertura comercial y la inversión extranjera directa. La importancia de este estudio se deriva del énfasis en la necesidad de IED protectoras del medio ambiente para reducir las emisiones de carbono.

Palabras clave: Emisión de carbono, Inversión Extranjera Directa (IED), apertura comercial, curva de Kuznets ambiental, hipótesis de refugio de contaminación, efecto halo.

JEL Classification: F18, Q56, C33

\section{INTRODUCTION}

Foreign Direct Investment plays an important, determinative key role in the economic development of countries. Countries with high trade openness attract more FDI as they are more integrated with the world. However, FDIs increase $\mathrm{CO} 2$ emission. $\mathrm{CO} 2$ emission, which is an important indicator of global warming, is also an important indicator of environmental pollution. Therefore, it is important to handle the impact of openness and FDI on CO2 emissions.

According to the World Development Indicator, the share of international trade in the world economy, which was $25 \%$ in the $1960 \mathrm{~s}$, increased to $58 \%$ in 2015 . Greenhouse gas emissions, $73 \%$ of which are $\mathrm{CO} 2$ emissions, have also increased rapidly due to the increase in trade openness. In this direction, in order to reduce greenhouse gas emissions and control global warming, the Kyoto Protocol was signed in 1997 and it was accepted 
with the agreement of the countries that make up more than $95 \%$ of global emissions (Zhang et al., 2017: 17616).

Kuznets (1955), in his study of the relationship between economic growth and income distribution inequality, argued that the increasing income inequality started to decrease after a certain turning point due to the continuation of economic development and this change was in the form of reverse- $U$ (Kuznets, 1955: 14). This hypothesis revealed by Kuznets Grossman and Krueger (1991) adapted it to economic growth and environmental pollution. In later studies, the relationship between income and environment was named as the environmental Kuznets curve (EKC) hypothesis (Grossman and Krueger, 1991).

The EKC hypothesis suggests that in the early stages of economic growth, environmental pollution will increase and environmental improvement will occur with an increase in income levels. This means that the environmental impact indicator is an inverted U-shaped function of per capita income (Stern, 2004: 1419).

The theoretical basis of the EKC hypothesis is the scale, composition and technical effect (Grossman and Krueger, 1995: 355): The scale effect means that fluctuations in trade lead to an increase in production and $\mathrm{CO} 2$ emissions. It also states that the expansion in the markets will increase the production and consumption, and the increase in pollution will increase. Composition effect, on the other hand, shows the allocation of traded goods and the effects of trade on pollution, Technical effect, on the other hand, increases the technological innovation with the trade openness, decreases the emission intensity, decreases the pollution and provides a cleaner environment (Barrett, 2000; Cole et al., 2006; Chebbi et al., 2011: 32; Dauda et al., 2021: 3).

FDI ensures that the technology is transferred to the host country. FDI contributes to both technological knowledge transfer and physical capital stock. At the same time, with the effect of technology transfer developing with trade openness, it helps companies to develop and make technological upgrading in the country where FDI has entered. The impact of technology transfer on environmental degradation through FDI depends on the inputs used in the production process (Shahbaz et al., 2019: 57).

As a result of foreign companies in developed countries that create pollution, shifting their production to developing countries, environmental degradation in these countries is called the Pollution Haven Hypothesis (Copeland and Taylor, 1994). In other words, FDI input increases $\mathrm{CO} 2$ emissions and environmental degradation. However, Pollution Halo Hypothesis which tests the increase in environmental quality in the host country with FDI entry, is also being investigated (Dauda et al., 2021: 3). According to Pollution Halo hypothesis, countries with high technology levels will have better management and less CO2 emissions (Shahbaz et al., 2011). Many studies have been carried out to support the Halo effect, which states that FDI entries reduce $\mathrm{CO} 2$ emissions by providing a cleaner environment.

To analyze the impact of FDI and trade openness on $\mathrm{CO} 2$ emissions, countries' share of $\mathrm{CO} 2$ emissions should be looked at. As a matter of fact, according to the data obtained from British Petroleum (BP) 's Statistical Review of World Energy 2017, (British Petroleum (BP) 's Statistical Review of World Energy, 2017). In 2019, the share of $\mathrm{CO} 2$ emissions from nonOECD countries was $64.8 \%$, and China (Pacific Asia's total 50.5\%) ranks first with a share of $28.8 \%$. EU's share is $9.7 \%$ (BP, 2019).

Therefore, the impact of trade openness and FDI entries on $\mathrm{CO} 2$ emissions can be either positive or negative. In this study, the effect of trade openness and FDI entries on $\mathrm{CO} 2$ emissions will be tested in $24 \mathrm{EU}$ countries (with the exception of Luxembourg, Cyprus and Malta). 


\section{LITERATURE REVIEW}

In this study, the literature review is examined in 3 parts. In the first part, the relationship between trade openness and carbon emission is discussed and the existence of the EKC hypothesis is tested. In the second stage, studies dealing with the relationship between FDI and $\mathrm{CO} 2$ emission, which is another variable, are included. In the last stage, studies that take FDI and trade openness together and compare them with $\mathrm{CO} 2$ emission are included.

The studies of Shahbaz et al. (2013), Akin (2014), Sbia et al. (2014), Kasman and Duman (2015), Zhang et al. (2017), Salman et al. (2019), Shahbaz et al. (2019), Lv and Xu (2019), Essandoh et al. (2020) support the EKC hypothesis and state that there is a negative relationship between trade openness and $\mathrm{CO} 2$ emission. One of these studies, Akin (2014) examined the period of 1990-2011 for 85 countries and found that the EKC hypothesis was valid in the long run and a positive relationship between $\mathrm{CO} 2$ emissions and trade openness in the short term. Examining the period 1992-2012 for 55 middle-income countries, $\mathrm{Lv}$ and $\mathrm{Xu}$ (2019) found that the EKC hypothesis was valid in the short term and there was a positive relationship between the variables in the long run.

There are also studies that don't support the EKC hypothesis and find a positive relationship between trade openness and $\mathrm{CO} 2$ emission for example Farhani et al. (2013), Ertugrul et al. (2016), Shahbaz et al. (2017), Dauda et al. (2021). Among these studies, Ertugrul et al. (2016) examined the impact of trade openness on $\mathrm{CO} 2$ emissions in 10 developing countries for the period 1971-2011. In conclusion, Turkey, India, China and Indonesia that the trade openness for the positive effects of $\mathrm{CO} 2$ emissions and for Brazil and China found that a bi-directional causality between trade openness with $\mathrm{CO} 2$ emissions.

In some of the studies between trade openness and $\mathrm{CO} 2$ emissions, the direction of the variables was determined by causality analysis. While Kasman and Duman (2015) found a one-way causality from trade openness to $\mathrm{CO} 2$ emissions. Akin (2014) found a one-way causality from $\mathrm{CO} 2$ emission to trade openness. In the study of Dogan and Turkekul (2016), it was found that there is no causality relationship between trade openness and $\mathrm{CO} 2$ emission. In some studies, foreign trade variable was used instead of trade openness. For example, Salman et al. (2019).

In the second stage, there are studies on the relationship between FDI and CO2. Most of the studies dealing with the relationship between FDI and $\mathrm{CO} 2$ test the existence of the pollution haven hypothesis (PHH). Shahbaz et al. (2015), Sun et al. (2017), studies supporting the PHH hypothesis were conducted. Among these studies, Shahbaz et al. (2015) examined the relationship between FDI and $\mathrm{CO} 2$ with three heterogeneous panels as high, middle and low income for 99 countries in the period 1975-2012. As a result of the study, they found a long-term relationship between variables and found that FDI entries increased $\mathrm{CO} 2$ emissions. In addition, Pollution Halo Hypothesis which tests the increase in environmental quality in the host country with FDI entry, is also being investigated (Dauda et al., 2021: 3).

Zubair et al. (2020) is among the studies supporting the Halo effect, which states that FDI entries reduce $\mathrm{CO} 2$ emission by providing a cleaner environment. Hoffmann et al. (2005) and Lee (2013) found that neither of these hypotheses were valid, and that there was no causality between FDI and CO2. There are also studies that investigated the direction of causation and identify a causality between variables. Omri et al. (2014) determined a bi-directional causality between FDI and $\mathrm{CO} 2$ emissions in 54 countries for the period 1990-2011; Dhrifi et al. (2020) found a unidirectional causality from FDI to $\mathrm{CO} 2$ emissions in 98 developing countries for the period 1995-2017.

Huang et al. (2019) is among the studies that examine the relationship between FDI and 
trade openness for China and its provinces and compare FDI and trade openness relation with CO2 emissions. Ren et al. (2014) examined the impact of foreign trade, trade openness and FDI on $\mathrm{CO} 2$ emissions in industrial sectors in China for the period 2000-2010. As a result of the study, it has been determined that increases in foreign trade, trade openness and FDI increase $\mathrm{CO} 2$ emissions. $1 \%$ increase in total trade increases the $\mathrm{CO} 2$ emission by $0.4 \%$; It was determined that a $1 \%$ increase in the FDI input increased the CO2 emission by $22.3 \%$.

In the literature it is seen that the studies are mostly directed at developing countries. For example, Kaya et al. (2017) studied the Turkey. Kaya et al. (2017) for the 1974-2010 period, FDI and trade openness in Turkey examined the impact of $\mathrm{CO} 2$ emissions on. The results of the study found that the increase in FDI and trade openness increased $\mathrm{CO} 2$ emissions, but there was a negative relationship between FDI and $\mathrm{CO} 2$ emissions in the short term.

For developed countries, these studies are not very common and have not been studied much. Among these studies, Shahbaz et al. (2019) examined the effect of FDI and trade clearance on $\mathrm{CO} 2$ emissions in the USA for the period 1965-2016. According to the results of the study, FDI has a positive effect on $\mathrm{CO} 2$ emission. This effect shows that the scale effect of FDI has a repressive effect. There is a negative impact between trade openness and $\mathrm{CO} 2$ emissions in the short and long term. In the long run, a $10 \%$ increase in trade openness reduces $\mathrm{CO} 2$ emissions by $1.45 \%$.

In some studies, the relationship between variables was tested by using foreign trade data instead of the trade openness variable. For example, Essandoh et al. (2020). Essandoh et al. (2020) examined the impact of FDI and foreign trade on $\mathrm{CO} 2$ emissions in 52 countries for the period 1991-2014. According to the results of the study, there is a positive relationship between FDI and $\mathrm{CO} 2$ emissions in low-income countries, while there is a negative relationship between trade openness and $\mathrm{CO} 2$ emissions in high-income countries.

\section{ECONOMETRIC ANALYSIS}

In this study, 24 EU member countries (Austria, Belgium, Bulgaria, Croatia, Czech Republic, Denmark, Estonia, Finland, France, Germany, Greece, Hungary, Ireland, Italy, Latvia, Lithuania, Netherlands, Poland, Portugal, Romania, Slovakia, Slovenia, Spain, Switzerland), for the period 1995-2019, the relationship between foreign direct investments, trade openness and $\mathrm{CO} 2$ emission is examined for $24 \mathrm{EU}$ member countries. Foreign direct investments, trade openness and $\mathrm{CO} 2$ emission data were obtained from the World Bank (data.worldbank.org). Econometric analyzes were analyzed using Stata 12.0 and Gauss 10.0 econometric programs.

For the econometric analysis of the study, Breusch and Pagan (1980) cross-section dependency, Pesaran and Yamagata (2008) Swamy test was used to test the homogeneity of variables. Im, Pesaran and Shin (CIPS) Panel Unit Root Test, which was later developed by Pesaran (2007), and for the estimation of long-term parameters of the long-term relationship between variables. The data were analyzed with the AMG (Extended Mean Group) estimator developed by Eberhardt and Bond and the panel causality test developed by Emirmahmutoglu and Kose (2011) were used.

\section{Cross Section Dependency Test}

In testing the cross-sectional dependency, in the LM test developed by Breusch and Pagan (1980), the CD test developed by Pesaran (2004) and the CDLMadj tests developed by Pesaran and Yamagata (2008), the mentioned hypotheses are as follows: While there is no cross section dependency according to the null hypothesis; according to the alternative hypothesis, there is a cross section dependence. Based on this, as can be seen in Table 1, in this study, it was first checked whether there is cross-sectional dependency in 
the variables and the model. In line with the results obtained, the hypothesis stating that there is no cross sectional dependency in the variables and the model was rejected. In other words, it is seen that there is cross-sectional dependency in the variables and model discussed in the study (Sahin \& Durmus, 2019: 191).

In this study, where the relationship of foreign direct investments, trade openness and $\mathrm{CO} 2$ emission is examined for $24 \mathrm{EU}$ countries, it is primarily necessary to test whether there is cross-section dependence in variables, that is, whether there is a correlation between units, in order to determine which unit root test should be used. CDLM test developed by Pesaran (2004) and Breusch-Pagan (1980) CDLM1 tests are used to determine the correlation between units. The CDLM1 test is the predictor that tests the correlation between units in the case of $\mathrm{T}>\mathrm{N}$, and the CDLM test is the predictor that tests the correlation between units in the case of $\mathrm{T}<\mathrm{N}$ (Dam, 2014: 108).

$$
C D=\sqrt{2 T / N(N-1)}\left(\sum_{\mathrm{I}=1}^{N-1} \sum_{J=i+1}^{N} \bar{P} y\right)
$$

In the equation 1, it is suggested that the cross section dependency test statistic expressed by (Pesaran, 2004) shows a normal distribution. Pesaran (2004) defines the null hypothesis of the CDLM test as "No Cross Section Dependence". In the case of examining the correlation between units with Pesaran (2004) CDLM test, finding a probability value less than 0.05 , the null hypothesis expressed as "No Cross Section Dependence" is rejected at the 5\% significance level. If the null hypothesis is rejected, it is concluded that there is a cross-sectional dependency between the variables in the panel (Recepoglu et al., 2020: 73, 74).

It is important in determining the cointegration and causality analyzes that are required to be used in the analysis aimed at determining whether the coefficients are homogeneous or heterogeneous in studies conducted with panel data analysis.

All countries / regions etc. which will be tested for homogeneity testing. It is expressed as the slope coefficients $\beta_{i}$ calculated for the equation to $\beta$, which is a single slope coefficient. Heterogeneity is explained as the difference of at least one of the slope coefficients $\beta_{i}$. Pesaran and Yamagata (2008) interpret the homogeneity of the coefficients with two different statistics: $\tilde{\Delta}$ (delta_tilde) ve $\widetilde{\Delta_{a d j}}($ delta_tilde_adj) (Gul and Inal, 2017). The homogeneity tests of the slope coefficients were made with the help of the delta test developed by Pesaran and Yamagata (2008) and calculated as in equations 2 and 3 below (Doganay and Deger, 2017: 133):

$\Delta=\sqrt{N} \frac{N^{-1} \breve{S}-K}{\sqrt{2 K}}$

Equation 3 gives the corrected form of the delta test statistic:

$\Delta_{a d j}=\sqrt{N} \frac{N^{-1} \breve{S}-E\left(\tilde{Z}_{i t}\right)}{\sqrt{\operatorname{Var}\left(\tilde{Z}_{i t}\right)}}$

For the delta test, it is tested by establishing two different hypotheses, $H_{0}$ : The slope coefficient is homogeneous and $H_{1}$ : he slope coefficient is not homogeneous. If the test statistics obtained from Equation 3 are less than $5 \%$, the $H_{0}$ hypothesis is rejected and the slope coefficients are said to be heterogeneous (Doganay and Deger, 2017: 133). 
Tab.1. Cross section dependency test results in variables

\begin{tabular}{|c|c|c|c|c|c|c|}
\hline \multirow{2}{*}{$\begin{array}{c}\text { Variables: } \\
\text { Tests }\end{array}$} & \multicolumn{2}{|c|}{ Co2 } & \multicolumn{2}{|c|}{ FDI } & \multicolumn{2}{|c|}{ Trade } \\
\hline & stat. & P-value & Stat. & P-value & stat. & P-value \\
\hline $\begin{array}{l}\text { CDLM1 } \\
\text { (Breusch, } \\
\text { Pagan,1980) }\end{array}$ & 1928.753 & 0.000 & 1344.528 & 0.000 & 1996.842 & 0.000 \\
\hline $\begin{array}{l}\text { CDLM2 } \\
\text { (Pesaran, } 2004 \\
\text { CDlm) }\end{array}$ & 70.346 & 0.000 & 45.480 & 0.000 & 73.244 & 0.000 \\
\hline $\begin{array}{l}\text { CDLM } \\
\text { (Pesaran, } 2004 \text { CD) }\end{array}$ & -2.286 & 0.011 & -2.58 & 0.012 & -3.070 & 0.001 \\
\hline $\begin{array}{l}\text { Bias-adjusted CD } \\
\text { test }\end{array}$ & 68.405 & 0.000 & 6.027 & 0.000 & 23.241 & 0.000 \\
\hline
\end{tabular}

In Tab. 1, various cross-section dependency tests were applied to variables, including Breusch and Pagan (1980) LM, Pesaran (2004) LM and CD and Baltagi, Feng and Kao (2012) LM cross-section dependency tests, and the homogeneity coefficients of the variables used in the analyzes, probe for each variables. Since (probability) values are less than $\mathrm{p}<0.05$ for the variables used in the analysis, there is a cross-sectional dependency in the variables. Pesaran CADF (2007) Panel Unit Root Test was applied, which is one of the second generation panel unit root tests.

Tab. 2. Cross section dependency test results in models

Model 1

\begin{tabular}{|c|c|c|c|c|c|c|}
\hline \multirow[t]{2}{*}{ Test } & $\begin{array}{l}\text { Y: Co2 } \\
\text { X: Trade }\end{array}$ & & \multicolumn{2}{|l|}{$\begin{array}{l}\text { Y: Trade } \\
\mathrm{X}: \mathrm{Co} 2\end{array}$} & \multicolumn{2}{|l|}{$\begin{array}{l}\text { Y: Trade } \\
\text { X: Fdi }\end{array}$} \\
\hline & $\begin{array}{c}\text { Test } \\
\text { statistics }\end{array}$ & $\mathrm{p}$-value & $\begin{array}{c}\text { Test } \\
\text { statistics }\end{array}$ & p-value & $\begin{array}{c}\text { Test } \\
\text { statistics }\end{array}$ & $\mathrm{p}$-value \\
\hline Delta_tilde & 18.157 & 0.000 & 17.838 & 0.000 & 1.017 & 0.015 \\
\hline Delta_tilde_adj & 19.304 & 0.000 & 18.966 & 0.000 & 1.081 & 0.014 \\
\hline \multirow{3}{*}{ Test } & \multicolumn{2}{|c|}{ Model 4} & \multicolumn{2}{|c|}{ Model 5} & \multicolumn{2}{|c|}{ Model 6} \\
\hline & $\begin{array}{l}\text { Y: Fdi } \\
\text { X: Trade }\end{array}$ & & $\begin{array}{l}\text { Y: Fdi } \\
\mathrm{X}: \mathrm{Co} 2\end{array}$ & & $\begin{array}{l}\text { Y: Co2 } \\
\text { X: Fdi }\end{array}$ & \\
\hline & $\begin{array}{c}\text { Test } \\
\text { statistics }\end{array}$ & P-value & $\begin{array}{c}\text { Test } \\
\text { statistics }\end{array}$ & $\mathrm{p}$-value & $\begin{array}{c}\text { Test } \\
\text { statistics }\end{array}$ & P-value \\
\hline Delta_tilde & 1.156 & 0.012 & 4.683 & 0.000 & 4.751 & 0.000 \\
\hline Delta_tilde_adj & 1.229 & 0.011 & 4.979 & 0.000 & 5.052 & 0.000 \\
\hline
\end{tabular}

\section{Model 2}

Model 3 
While determining the appropriate unit root test and cointegration test for panel data analysis, besides the cross-section dependency, homogeneity test results are also important as determining which unit root and cointegration tests will be used. As can be seen from Tab. 2, Pesaran and Yamagata (2008) homogeneity test findings are given. Since each variable is taken as the dependent variable, the model is constructed and according to the homogeneity coefficients for each model, probability) values $\mathrm{p}<0.05$ are small, it is concluded that the coefficients of $\beta_{-} i$ for each model are not homogeneous, that is heterogeneous.

The cross-sectional dependency between the units forming the panel and the stationary properties of the variables were examined by the Im, Pesaran and Shin (CIPS) Panel Unit Root test developed by Pesaran (2007). Pesaran, Cross-Sectionally Augmented Dickey Fuller (CADF) test is applied to the panel regression model stated below and the stationarities of the variables are examined by using the $t$ statistics values of the $\hat{b}_{i}$ coefficients for the estimated model (Pesaran, 2007: 267- 269):

$\Delta y_{i, t}=a_{i}+b_{i} y_{i, t-1}+c_{i} \bar{y}_{i, t-1}+d_{i} \Delta \bar{y}_{i, t-1}+e_{i t}$

The hypothesis that "each cross section is not stationary" is tested against the hypothesis that "some of the cross sections are stationary". Pesaran names the arithmetic mean of the CADF test statistics as Cross-sectionally Augmented IPS (CIPS) test statistics and uses this test to examine the stationarity properties of the panel data series. CIPS test has a standard normal distribution asymptotically and is calculated as follows (Acaravc1 et al., 2015: 124):

$$
C I P S=N^{-1} \sum_{i=1}^{N} C A D F_{i}
$$

Tab. 3. Im, Pesaran and Shin (CIPS) panel unit root test

\begin{tabular}{clcc}
\hline \multirow{2}{*}{ Variables } & \multicolumn{3}{c}{ CIPS test } \\
\cline { 2 - 4 } & \multicolumn{1}{c}{$\mathbf{I}(\mathbf{0})$} & $\mathbf{Z}$ (t-bar) & p-value \\
\hline Fdi & $-4.719^{* *}$ & -15.146 & 0.000 \\
\hline Trade & $-4.320^{* *}$ & -13.114 & 0.000 \\
\hline Co2 & $-4.784^{* *}$ & -15.477 & 0.000 \\
\hline \multirow{2}{*}{ Critical Value } & $\% 1:-2.300$ & \\
& $\% 5:-2.150$ & \\
& $\% 10:-2.070$ & \\
& \multicolumn{2}{c}{ Source: own research }
\end{tabular}

Tab. 3 shows the CIPS test results. Since the t-bar (CIPS) statistic is larger in absolute value than the critical values given at the $90 \%$ (cv10), 95\% (cv5) and 99\% (cv1) confidence level, the series is interpreted as stationary at the level for all three variables. In addition, according to the probability values of the $\mathrm{Z}$ [t-bar] statistic, it is seen that the series are stationary at the level.

Eberhardt and Bond recommend AMG estimator, one of the second generation estimators (Baysal Kar, 2019: 423, 430), to estimate the longterm parameters of the long-term relationship between variables for the models used to make the analysis. As a result of the homogeneity and cross-section dependence tests performed to estimate the long-term coefficients, it was determined that the model is heterogeneous and includes cross-section dependence. Therefore, using a method that takes into account the crosssectional dependency between countries and the heterogeneous structure of the countries while making estimates will make it possible to obtain more accurate results. For this reason, the AMG estimator, which takes these two cases into account, was used for estimation. AMG 
estimator; It is a method that takes into account common dynamic effects as well as common factors in series. It also allows the calculation of different coefficients for cross sections. This estimator calculates a coefficient belonging to the entire panel in homogeneous models, and in heterogeneous models, it calculates a unit coefficient for each unit and the group average for the panel based on the weighted averages of these coefficients (Polat, 2018: 519). In Tab. 4, 5 and 6, the results of the analysis are interpreted by establishing three different models in which the variables of foreign direct investments, trade deficit and $\mathrm{CO} 2$ emission are taken as dependent variables, respectively, for the estimation results of AMG.

Tab. 4. AMG prediction results

\section{Model 1: FDI $=a+\beta 1$ Trade $+\beta 2 \operatorname{co2}+u$}

\begin{tabular}{|c|c|c|c|c|}
\hline \multirow{2}{*}{ Countries } & \multicolumn{2}{|c|}{ Trade } & \multicolumn{2}{|c|}{$\mathrm{Co} 2$} \\
\hline & coefficient & p-value & coefficient & p-value \\
\hline Austria & -.3490 & 0.588 & .51727 & 0.379 \\
\hline Belgium & 2.2273 & $0.003 * *$ & .43063 & 0.488 \\
\hline Bulgaria & .15423 & 0.137 & -.0445 & 0.822 \\
\hline Croatia & -.0331 & 0.531 & .6972 & $0.012 * *$ \\
\hline Czech Rep. & -.0530 & 0.522 & -.2803 & 0.064 \\
\hline Denmark & -.1259 & 0.673 & -.1181 & 0.613 \\
\hline Estonia & -.0256 & 0.749 & -.3839 & 0.587 \\
\hline Finland & -.1121 & 0.676 & -.1443 & 0.482 \\
\hline France & .3540 & $0.000 * *$ & -.0102 & 0.480 \\
\hline Germany & .0530 & 0.850 & .0062 & 0.849 \\
\hline Greece & .0089 & 0.744 & -.0291 & 0.171 \\
\hline Hungary & -.9121 & $0.022 * *$ & -.9324 & 0.571 \\
\hline Ireland & -.4604 & 0.188 & 1.6770 & 0.263 \\
\hline Italy & .11137 & 0.264 & .01150 & 0.453 \\
\hline Latvia & .12502 & $0.044 * *$ & .66179 & 0.351 \\
\hline Lithuania & -.0763 & 0.117 & .9499 & $0.012 * *$ \\
\hline Netherland & .1533 & 0.888 & .5581 & 0.462 \\
\hline Poland & .09756 & 0.104 & .0146 & 0.407 \\
\hline Portugal & .01954 & 0.923 & -.1355 & 0.324 \\
\hline Romania & -.3963 & 0.688 & -.0042 & 0.928 \\
\hline Slovakia & -.0518 & 0.500 & -.1296 & 0.847 \\
\hline Slovenia & .0917 & 0.378 & -.9260 & 0.180 \\
\hline Spain & .2555 & $0.001 * *$ & .00017 & 0.989 \\
\hline Switzerland & .4454 & $0.086^{*}$ & .6569 & $0.078 *$ \\
\hline Panel General & .0774 & 0.476 & .1267 & 0.276 \\
\hline
\end{tabular}

Wald chi2 : 1.51

Prob > chi2: 0.469 
It is seen that the model in which foreign direct investment is taken as the dependent variable expressed in Tab. 4 is insignificant since it is $0.469>p=0.05$ for the panel in general. A positive and statistically significant relationship was found for France, Latvia, Spain and Switzerland from trade openness to foreign direct investment. A positive and statistically significant relationship was found for Croatia, Lithuania and Switzerland among foreign direct investments from CO2 emissions.

Tab. 5. AMG prediction results

\begin{tabular}{|c|c|c|c|c|}
\hline \multicolumn{5}{|c|}{ Model 2: Trade $=a+\beta 1 F d i+\beta 2 \operatorname{co} 2+u$} \\
\hline \multirow{2}{*}{ Countries } & \multicolumn{2}{|c|}{ FDI } & \multicolumn{2}{|c|}{ Co2 } \\
\hline & coefficient & p-value & coefficient & p-value \\
\hline Austria & -0.436 & 0.588 & .53206 & $0.002 * *$ \\
\hline Belgium & .14014 & $0.003 * *$ & .04518 & 0.774 \\
\hline Bulgaria & .67688 & 0.137 & .58479 & 0.137 \\
\hline Croatia & -.6102 & 0.531 & 1.2220 & 0.364 \\
\hline Czech Rep. & -.3981 & 0.522 & .25675 & 0.566 \\
\hline Denmark & -.0738 & 0.673 & -.1859 & 0.288 \\
\hline Estonia & -.2080 & 0.749 & 3.9555 & $0.029 * *$ \\
\hline Finland & -.0811 & 0.676 & -.1809 & 0.292 \\
\hline France & 1.6282 & $0.000 * *$ & .0518 & $0.074 *$ \\
\hline Germany & .03531 & 0.850 & -.0836 & $0.000 * *$ \\
\hline Greece & .61856 & 0.744 & .1998 & 0.265 \\
\hline Hungary & -.2359 & $0.022 * *$ & -1.976 & $0.005 * *$ \\
\hline Ireland & -.1814 & 0.188 & 2.2837 & $0.005 * *$ \\
\hline Italy & .55273 & 0.264 & .00130 & 0.970 \\
\hline Latvia & 1.4094 & $0.044 * *$ & .78598 & 0.746 \\
\hline Lithuania & -1.501 & 0.117 & 3.902 & $0.024 * *$ \\
\hline Netherland & .0068 & 0.888 & -.3628 & $0.009 * *$ \\
\hline Poland & 1.253 & 0.104 & -.1118 & $0.059 *$ \\
\hline Portugal & .0254 & 0.923 & .1287 & 0.415 \\
\hline Romania & -.2128 & 0.688 & .2525 & $0.005 * *$ \\
\hline Slovakia & -.4503 & 0.500 & -.7633 & 0.700 \\
\hline Slovenia & .4283 & 0.378 & .2600 & 0.868 \\
\hline Spain & 1.476 & $0.001 * *$ & .0012 & 0.966 \\
\hline Switzerland & .3014 & $0.086^{*}$ & -.4349 & 0.168 \\
\hline Panel General & 1989 & 0.201 & .4318 & 0.106 \\
\hline $\begin{array}{l}\text { Wald chi2 }: 6.45 \\
\text { Prob > chi2: } 0.039\end{array}$ & & & & \\
\hline
\end{tabular}


It is seen that trade openness is taken dependent variable in Tab. 5 since the model in which the 0.039 $<p=0.05$ is significant. A positive and statistically significant relationship was found for Belgium, France, Hungary, Latvia and Spain from trade openness to foreign direct investment. A positive and statistically significant correlation was found for Austria, Estonia, France, Germany, Hungary, Ireland, Lithuania, the Netherlands, Poland and Romania from $\mathrm{CO} 2$ emission to trade openness.

Tab. 6. AMG prediction results

\begin{tabular}{|c|c|c|c|c|}
\hline \multicolumn{5}{|c|}{ Model 3: $\mathbf{C o 2}=\mathbf{a}+\beta 1 \mathrm{Fdi}+\boldsymbol{\beta 2 T r a d e}+\mathrm{u}$} \\
\hline \multirow{2}{*}{ Countires } & \multicolumn{2}{|c|}{ FDI } & \multicolumn{2}{|c|}{ Trade } \\
\hline & coeficient & p-value & coefficient & p-value \\
\hline Austria & .0756 & 0.379 & .6222 & $0.002 * *$ \\
\hline Belgium & .0572 & 0.488 & .0954 & 0.774 \\
\hline Bulgaria & -.0594 & 0.822 & .1779 & 0.137 \\
\hline Croatia & .3567 & $0.012 * *$ & .0339 & 0.364 \\
\hline Czech Rep. & -.5447 & $0.064 *$ & .0664 & 0.566 \\
\hline Denmark & -.1121 & 0.613 & -.3013 & 0.288 \\
\hline Estonia & -.0397 & 0.587 & .0505 & $0.029 * *$ \\
\hline Finland & -.1759 & 0.482 & -.3049 & 0.292 \\
\hline France & -2.510 & 0.480 & 2.773 & $0.074 *$ \\
\hline Germany & .3027 & 0.849 & -6.044 & $0.000^{* *}$ \\
\hline Greece & -3.075 & 0.171 & .30700 & 0.265 \\
\hline Hungary & -.0178 & 0.571 & -.1461 & $0.005^{* *}$ \\
\hline Irlanda & .0369 & 0.263 & .1277 & $0.005^{* *}$ \\
\hline Italy & 2.503 & 0.453 & .0572 & 0.970 \\
\hline Latvia & .0661 & 0.351 & .0069 & 0.746 \\
\hline Lithuania & .2603 & $0.012 * *$ & .0543 & $0.024 * *$ \\
\hline Netherlands & .0495 & 0.462 & -.7242 & $0.009^{* *}$ \\
\hline Poland & 2.378 & 0.407 & -1.413 & $0.059^{*}$ \\
\hline Portugal & -.3586 & 0.324 & .2619 & 0.415 \\
\hline Romania & -.1021 & 0.928 & 1.149 & $0.005^{* *}$ \\
\hline Slovakia & -.0149 & 0.847 & -.0101 & 0.700 \\
\hline Slovenia & -.0931 & 0.180 & .0056 & 0.868 \\
\hline Spain & .06000 & 0.989 & .0747 & 0.966 \\
\hline Switzerland & .21369 & $0.078^{*}$ & -.2090 & 0.168 \\
\hline Panel General & -.0310 & 0.891 & -.1370 & 0.644 \\
\hline \multicolumn{5}{|l|}{ Wald chi2 $\quad: 0.32$} \\
\hline Prob > chi2 : 0.853 & & & & \\
\hline
\end{tabular}

It is seen that the model in which the $\mathrm{CO} 2$ emission expressed in Tab. 6 is taken as the dependent variable is not significant since it is $0.853>p=0.05$. A positive and statistically significant relationship was found for Croatia, Czech Republic and Switzerland from foreign direct investments to $\mathrm{CO} 2$ emissions. On the other hand, from trade openness to $\mathrm{CO} 2$ emission, a positive and statistically significant relationship was found for Estonia, France, Ireland, Lithuania, Poland and Romania, while a negative and statistically significant relationship was found for Germany, Hungary and the Netherlands. 
Emirmahmutoglu and Kose (2011) panel causality test is a causality test on the assumption of heterogeneity of the coefficients. It does not matter whether the variables are stable or cointegrated. Due to the characteristics of heterogeneous panel data models, estimates are made for each section in the panel and for all cuts in terms of time dimension. The panel is a heterogeneous test and the VAR model parameters can be estimated for each section in the panel. In this test, causality analysis of level variables can be performed without taking into account the time series properties of variables in the VAR model. Granger causality analysis can be performed separately and in general for each section in the panel. Emirmahmutoglu and Kose (2011) panel causality test since it is an extended form of Toda-Yamamoto (1995) test to heterogeneous panel data, there is no need to apply unit root and cointegration tests, which is the advantage of Toda-Yamamoto (1995) test, also valid for Emirmahmutoglu and Kose (2011) test. (Emirmahmutoglu and Kose, 2011: 103). In Emirmahmutoglu and Kose (2011) test, VAR model for each section is estimated as indicated in equation 6 :

$Y_{i t}=\mu_{i}+A_{1 i} y_{i(t-1)}+\cdots+A_{p i} y_{i(t-p i)}+\cdots+A_{(p+d) i} y_{i(t-p i-d i)}+\varepsilon_{i t}$

Where $y_{i t}$ is the vector of endogenous variables. $\mu_{i}$ is the p-dimensional vector of constant effects, $p_{i}$ is the optimal delay and $d_{i}$ is the maximum cointegration degree of the variables. In order to test the Granger causality hypothesis for panel data analysis, Fisher statistics is expressed as in equation 7:

$\lambda=-2 \sum_{i=1}^{N} \ln \left(\pi_{i}\right)$

Tab. 7. Emirmahmutoglu and Kose panel causality test results

\begin{tabular}{llll}
\hline \multicolumn{1}{c}{ Causality Direciton } & \multicolumn{1}{c}{ Panel Fisher } & \multicolumn{1}{c}{ P-val } & Causality \\
\hline Trade $\rightarrow$ Co2 & 15.602 & 1.000 & No \\
\hline Co2 $\rightarrow$ Trade & 97.287 & $0.000^{* *}$ & Yes \\
\hline Fdi $\rightarrow$ Trade & 66.318 & $0.041^{* *}$ & Yes \\
\hline Trade $\rightarrow$ Fdi & 59.108 & 0.131 & No \\
\hline $\mathbf{C o 2} \rightarrow$ Fdi & 265.105 & $0.000^{* *}$ & Yes \\
\hline Fdi $\rightarrow$ Co2 & 47.729 & 0.484 & No \\
\hline \multicolumn{2}{c}{ Source: own research }
\end{tabular}

In Tab. 7, panel causality test results are given for the panel in general. It is concluded that there is a unidirectional causality relationship from $\mathrm{CO} 2$ emissions to trade openness, from foreign direct investments to trade openness, and from $\mathrm{CO} 2$ emissions to foreign direct investments.

Tab. 8. Emirmahmutoglu and Kose panel causality test results

\begin{tabular}{|c|c|c|c|c|c|c|}
\hline & \multicolumn{3}{|c|}{ Trade to Co2 } & \multicolumn{3}{|c|}{ Co2 to Trade } \\
\hline $\mathbf{i}$ & Lag & Wald & p-val & Lag & Wald & p-val \\
\hline Austria & 1.000 & 0.380 & 0.538 & 1.000 & 1.985 & 0.159 \\
\hline Belgium & 1.000 & 0.323 & 0.570 & 1.000 & 1.699 & 0.192 \\
\hline Bulgaria & 1.000 & 0.006 & 0.940 & 1.000 & 3.093 & $0.079 *$ \\
\hline Croatia & 1.000 & 0.001 & 0.974 & 1.000 & 2.092 & 0.148 \\
\hline Czech Rep. & 1.000 & 0.002 & 0.966 & 1.000 & 1.553 & 0.213 \\
\hline Denmark & 1.000 & 0.017 & 0.896 & 1.000 & 0.916 & 0.399 \\
\hline
\end{tabular}




\begin{tabular}{lllllll}
\hline Estonia & 1.000 & 0.015 & 0.902 & 1.000 & 1.336 & 0.248 \\
\hline Finland & 1.000 & 0.099 & 0.753 & 1.000 & 0.895 & 0.344 \\
\hline France & 1.000 & 0.064 & 0.801 & 1.000 & 1.356 & 0.244 \\
\hline Germany & 1.000 & 0.039 & 0.844 & 1.000 & 1.655 & 0.198 \\
\hline Greece & 1.000 & 0.001 & 0.973 & 1.000 & 2.066 & 0.151 \\
\hline Humgary & 1.000 & 0.064 & 0.801 & 1.000 & 1.944 & 0.163 \\
\hline Ireland & 1.000 & 0.001 & 0.980 & 1.000 & 2.242 & 0.134 \\
\hline Italy & 1.000 & 0.591 & 0.442 & 1.000 & 3.466 & $0.063^{*}$ \\
\hline Latvia & 1.000 & 0.165 & 0.684 & 1.000 & 3.767 & $0.052^{*}$ \\
\hline Lithuania & 1.000 & 0.025 & 0.875 & 1.000 & 2.706 & 0.100 \\
\hline Netherlands & 1.000 & 0.152 & 0.697 & 1.000 & 2.430 & 0.119 \\
\hline Poland & 1.000 & 0.554 & 0.457 & 1.000 & 4.949 & $0.026^{* *}$ \\
\hline Portugal & 1.000 & 0.028 & 0.866 & 1.000 & 3.211 & $0.073^{*}$ \\
\hline Romania & 1.000 & 0.069 & 0.792 & 1.000 & 2.308 & 0.129 \\
\hline Slovakia & 1.000 & 0.224 & 0.636 & 1.000 & 2.382 & 0.123 \\
\hline Slovenia & 1.000 & 0.159 & 0.690 & 1.000 & 4.057 & $0.044^{* *}$ \\
\hline Spain & 1.000 & 1.003 & 0.317 & 1.000 & 1.878 & 0.171 \\
\hline Switzerland & 1.000 & 0.279 & 0.597 & 1.000 & 1.364 & 0.243 \\
\hline Panel Fisher : 15.602 & & & Panel Fisher & $: 97.287$ & \\
\hline p-value & $: 1.000$ & & & p-value & $: 0.000^{* *}$ & \\
\hline
\end{tabular}

Source: own research

In Tab. 8, panel causality test results, causality relationship analysis findings from commercial openness to $\mathrm{CO} 2$ release and from $\mathrm{CO} 2$ release to trade openness are analyzed on country basis. Since the causality relationship from $\mathrm{CO} 2$ release to trade openness is significant for the panel overall (p-value: $0.000<0.05$ ), there is a causality relationship in EU countries. In addition, when examined on the basis of countries, a causality relationship from $\mathrm{CO} 2$ emission to trade openness was found for Bulgaria, Italy, Latvia, Poland, Portugal and Slovenia.

Tab. 9. Emirmahmutoglu and Kose panel causality test results

\begin{tabular}{lllllll}
\hline & \multicolumn{2}{c}{ FDI to Trade } & & \multicolumn{3}{c}{ Trade to FDI } \\
\hline \multicolumn{1}{c}{$\mathbf{i}$} & \multicolumn{1}{c}{ Lag } & Wald & p-val & \multicolumn{1}{c}{ Lag } & Wald & p-val \\
\hline Austria & 1.000 & 0.254 & 0.614 & 1.000 & 1.530 & 0.216 \\
\hline Belgium & 1.000 & 2.093 & 0.148 & 1.000 & 0.001 & 0.975 \\
\hline Bulgaria & 1.000 & 4.000 & $0.045^{* *}$ & 1.000 & 4.298 & $0.038^{* *}$ \\
\hline Croatia & 1.000 & 0.751 & 0.386 & 1.000 & 0.032 & 0.857 \\
\hline Czech Rep. & 1.000 & 0.209 & 0.647 & 1.000 & 0.517 & 0.472 \\
\hline Denmark & 2.000 & 4.063 & 0.131 & 2.000 & 3.659 & 0.161 \\
\hline Estonia & 2.000 & 0.258 & 0.879 & 2.000 & 2.351 & 0.309 \\
\hline Finland & 2.000 & 3.053 & 0.217 & 2.000 & 9.111 & $0.011^{* *}$ \\
\hline France & 1.000 & 0.027 & 0.870 & 1.000 & 0.022 & 0.883 \\
\hline Germany & 1.000 & 3.941 & $0.047^{* *}$ & 1.000 & 8.200 & $0.004^{* *}$ \\
\hline Greece & 1.000 & 4.270 & $0.039^{* *}$ & 1.000 & 2.091 & 0.148 \\
\hline
\end{tabular}




\begin{tabular}{|c|c|c|c|c|c|c|}
\hline Hungary & 1.000 & 0.068 & 0.795 & 1.000 & 0.110 & 0.740 \\
\hline Ireland & 1.000 & 0.012 & 0.911 & 1.000 & 0.027 & 0.868 \\
\hline Italy & 1.000 & 0.054 & 0.816 & 1.000 & 1.252 & 0.263 \\
\hline Latvia & 2.000 & 1.425 & 0.490 & 2.000 & 0.158 & 0.924 \\
\hline Lithuania & 2.000 & 0.268 & 0.605 & 2.000 & 0.838 & 0.360 \\
\hline Netherlands & 1.000 & 4.236 & 0.120 & 1.000 & 0.392 & 0.822 \\
\hline Poland & 2.000 & 1.903 & 0.386 & 1.000 & 1.350 & 0.509 \\
\hline Portugal & 1.000 & 0.376 & 0.540 & 1.000 & 0.513 & 0.474 \\
\hline Romania & 1.000 & 4.162 & $0.041 * *$ & 1.000 & 0.196 & 0.658 \\
\hline Slovakia & 1.000 & 8.315 & $0.004 * *$ & 1.000 & 0.464 & 0.496 \\
\hline Slovenia & 1.000 & 0.147 & 0.702 & 1.000 & 1.684 & 0.194 \\
\hline Spain & 1.000 & 0.365 & 0.546 & 1.000 & 0.023 & 0.880 \\
\hline Switzerland & 1.000 & 0.864 & 0.353 & 1.000 & 1.308 & 0.253 \\
\hline Panel Fisher & $: 66.318$ & & & Panel H & $: 59.108$ & \\
\hline p-value & $: 0.041^{* *}$ & & & p-value & $: 0.131$ & \\
\hline
\end{tabular}

In Tab. 9, panel causality test results, causality relationship analysis findings from foreign direct investments to trade openness and from trade openness to foreign direct investments are analyzed on a country basis. Since the causality relationship from foreign direct investment to trade openness is significant for the panel overall (p-value: $0.041<0.05$ ), there is a causality relationship in EU countries. In addition, when analyzed on the basis of countries, there is a causality relationship from foreign direct investments to trade openness for Bulgaria, Germany, Greece, Romania and Slovakia. Again, the causality relationship from trade openness to foreign direct investments on country basis is valid for Bulgaria, Finland and Germany.

Tab. 10. Emirmahmutoglu ve Kose panel causality test results

Co2 to FDI

\begin{tabular}{lllllll}
\hline \multicolumn{1}{c}{ i } & \multicolumn{1}{c}{ Lag } & \multicolumn{1}{c}{ Wald } & \multicolumn{1}{c}{ p-val } & \multicolumn{1}{c}{ Lag } & Wald & \multicolumn{1}{c}{ p-val } \\
\hline Austria & 2.000 & 20.380 & $0.000^{* *}$ & 2.000 & 2.694 & 0.260 \\
\hline Belgium & 1.000 & 0.396 & 0.529 & 1.000 & 0.183 & 0.669 \\
\hline Bulgaria & 1.000 & 0.235 & 0.628 & 1.000 & 1.736 & 0.188 \\
\hline Croatia & 1.000 & 0.223 & 0.637 & 1.000 & 0.653 & 0.419 \\
\hline Czech Rep. & 1.000 & 0.586 & 0.444 & 1.000 & 0.579 & 0.447 \\
\hline Denmark & 3.000 & 44.736 & $0.000^{* *}$ & 3.000 & 1.317 & 0.725 \\
\hline Estonia & 3.000 & 51.937 & $0.000^{* *}$ & 3.000 & 2.236 & 0.525 \\
\hline Finland & 3.000 & 30.923 & $0.000^{* *}$ & 3.000 & 7.189 & $0.066^{*}$ \\
\hline France & 3.000 & 29.243 & $0.000^{* *}$ & 3.000 & 4.733 & 0.192 \\
\hline Germany & 2.000 & 7.839 & $0.020^{* *}$ & 2.000 & 3.427 & 0.180 \\
\hline Greece & 1.000 & 0.174 & 0.676 & 1.000 & 0.186 & 0.666 \\
\hline Hungary & 1.000 & 0.661 & 0.416 & 1.000 & 0.060 & 0.807 \\
\hline Ireland & 1.000 & 0.213 & 0.644 & 1.000 & 0.000 & 0.997 \\
\hline Italy & 1.000 & 0.863 & 0.353 & 1.000 & 0.194 & 0.659 \\
\hline Latvia & 1.000 & 0.588 & 0.443 & 1.000 & 0.201 & 0.654 \\
\hline
\end{tabular}




\begin{tabular}{|c|c|c|c|c|c|c|}
\hline Lithuania & 1.000 & 0.103 & 0.748 & 1.000 & 0.523 & 0.470 \\
\hline Netherland & 1.000 & 0.997 & 0.318 & 1.000 & 0.059 & 0.808 \\
\hline Poland & 3.000 & 18.094 & $0.000^{* *}$ & 3.000 & 0.229 & 0.973 \\
\hline Portugal & 1.000 & 5.206 & $0.023^{* *}$ & 1.000 & 1.314 & 0.252 \\
\hline Romania & 1.000 & 1.435 & 0.231 & 1.000 & 3.862 & $0.049 * *$ \\
\hline Slovakia & 1.000 & 0.627 & 0.428 & 1.000 & 3.690 & $0.055^{*}$ \\
\hline Slovenia & 1.000 & 0.955 & 0.328 & 1.000 & 0.272 & 0.602 \\
\hline Spain & 3.000 & 35.962 & $0.000^{* *}$ & 3.000 & 1.003 & 0.800 \\
\hline Switzerland & 2.000 & 15.515 & $0.000 * *$ & 2.000 & 2.473 & 0.290 \\
\hline \multicolumn{3}{|c|}{ Panel Fisher : 265.105} & \multicolumn{4}{|c|}{ Panel Fisher : 47.729} \\
\hline p-value & \multicolumn{3}{|l|}{$: 0.000^{* *}$} & p-value & \multicolumn{2}{|l|}{$: 0.484$} \\
\hline
\end{tabular}

Source: own research

In Tab 10, panel causality test results, causality relationship analysis findings from $\mathrm{CO} 2$ emissions to foreign direct investments and from foreign direct investments to $\mathrm{CO} 2$ emissions are analyzed on a country basis. Since the causality relationship from $\mathrm{CO} 2$ release to foreign direct investments is significant for the panel general (p-value: $0.000<0.05$ ), there is a causality relationship in EU countries. In addition, when examined on the basis of countries, there is a causality relationship from $\mathrm{CO} 2$ emissions to foreign direct investments for Austria, Denmark, Estonia, Finland, France, Germany, Poland, Portugal, Spain and Switzerland. Again, the causality relationship from foreign direct investments to trade openness on a country basis is valid for Finland, Romania and Slovakia.

\section{CONCLUSIONS}

In terms of its economic dimension, foreign direct investments have important contributions to the economic growth and development processes of countries. In times when country savings are insufficient, as Omisakin (2009) stated, foreign direct investments provide foreign resources for the investments of countries by providing capital formation. Trade openness plays a key role for countries that want to take advantage of foreign direct investment. While the level of commercial openness of countries has an effect on capital mobility, it also serves as an important indicator for countries to gain competitive advantage.

Foreign direct investments have advantages for countries as well as disadvantages. While foreign direct investments provide advantages by increasing the employment and production level of countries as well as technological development and competition levels, they also have negative effects on human health by causing environmental degradation by increasing the $\mathrm{CO} 2$ emission. While foreign direct investments are important for underdeveloped and developing countries in terms of their positive effects on countries, they are not preferred by developed countries due to their negative aspects.

In this study, the relationship between foreign direct investments, trade openness and $\mathrm{Co} 2$ emissions was cross-section dependency and Emirmahmutoglu and Kose (2011) panel causality tests for the estimation of long-term parameters.

According to the panel causality test findings of Emirmahmutoglu and Kose (2011), when the panel is interpreted in general, it is found that there is a one-way causality relationship from $\mathrm{CO} 2$ emission to trade openness, from foreign direct investments to trade openness and from $\mathrm{CO} 2$ emission to foreign direct investments for 24 EU member countries. 
When the panel causality test results were examined on the basis of countries, a causality relationship from $\mathrm{Co} 2$ emission to trade clearance was found for Bulgaria, Italy, Latvia, Poland, Portugal and Slovenia. For Bulgaria, Germany, Greece, Romania and Slovakia, there is a causal relationship from foreign direct investment to trade openness. The causality relationship from trade openness to foreign direct investment applies to Bulgaria, Finland and Germany. For Austria, Denmark, Estonia, Finland, France, Germany, Poland, Portugal, Spain and Switzerland, there is a causal relationship from $\mathrm{Co} 2$ emissions to foreign direct investments. It is concluded that the causality relationship from foreign direct investment to trade openness is valid for Finland, Romania and Slovakia.

\section{REFERENCES}

1. Acaravc1, A., Bozkurt, C, \& Erdogan, S. (2015). Democracy-Economic Growth Relationship in Mena Countries. Journal of Business and Economics Studies, 3 (4), 119-129.

2. Akin, C.S. (2014). The Impact of Foreign Trade, Energy Consumption and Income on Co2 Emissions. International Journal of Energy Economics and Policy, 4 (3), 465-475.

3. Barrett, S. (2000). Trade and environment: local versus multilateral reforms. Environment and Development Economics, 5 (4), 349-359. https://doi.org/10.1017/S1355770X0000022X

4. Baysal Kar, B. (2019), Financialization and Income Inequality: A Comparative Analysis for Different Types of Capitalism, Journal of Yasar University, 14 (56), 422-440.

5. Breusch, T.S. and Pagan, A.R. (1980). The Lagrange Multiplier Test and its Applications to Model Specification Tests in Econometrics. Review of Economic Studies, 47 (1), 239-253.

6. BP (2019). British Petroleum Statistical Review of World Energy 2019, London.

7. Chebbi, H.E., Olarreaga, M. and Zitouna, H. (2011). Trade openness and CO2 emissions in Tunisia. Middle East Development Journal, 3(1), 29-53. https://doi.org/10.1142/S1793812011000314

8. Cole, M.A., Elliott, R.J.R. and Fredriksson, P.G. (2006). Endogenous Pollution Havens: Does Fdi Influence Environmental Regulations? Scandinavian Journal of Economics, 108 (1), 157-178. DOI: $10.1111 / \mathrm{j} .1467-9442.2006 .00439 . x$

9. Copeland, B.R. and Taylor, M.S. (1994). North-South Trade and the Environment. The Quarterly Journal of Economics, 109 (3), 755-787.

10. Dam, M., M. (2014). The Relationship of Greenhouse Gas Emissions with Macroeconomic Variables: Panel Data Analysis for OECD Countries. (Unpublished Doctoral Thesis). Adnan Menderes University Institute of Social Sciences, Aydin.

11. Dauda, L., Long, X., Menah, C.N., Salman, M., Boamah, K.B., Ampon-Wireko, S.and Dogbe, C.S.K. (2021). Innovation, Trade Openness and Co2 Emissions in Selected Countries in Africa. Journal of Cleaner Production, 281 (125143), 1-11. https://doi.org/10.1016/j.jclepro.2020.125143

12. Dhrifi, A., Jaziri, R.and Alnahdi, S. (2020). Does Foreign Direct Investment and Environmental Degradation Matter For Poverty? Evidence From Developing Countries. Structural Change and Economic Dynamics, 52, 13-21. https://doi.org/10.1016/j.strueco.2019.09.008

13. Dogan, E. and Turkekul, B. (2016). Co2 Emissions, Real Output, Energy Consumption, Trade, Urbanization and Financial Development: Testing The Ekc Hypothesis For the USA. Environ Sci Pollut Res. 23, 1203-1213.

14. Doganay, M.A. and Deger, M.K. (2017). Foreign Direct Investments and Export Relations in Emerging Market Economies: Panel Data Cointegration Analyses (1996-2014). Çankırı Karatekin University Journal of The Faculty of Economics and Administrative Sciences, 7 (2), 127-145.

15. Emirmahmutoğlu, F. ve Köse, N. (2011). Testing for Granger Causality in Heterogeneous Mixed Panels. Economic Modelling, 28, 870-876.

16. Ertugrul, H.M., Cetin, M., Seker, F. and Dogan, E. (2016). The Impact of Trade Openness on Global Carbon Dioxide Emissions:Evidence From The Top Ten Emitters Among Developing Countries. Ecological Indicators, 67, 543-555. https://doi.org/10.1016/j.ecolind.2016.03.027

17. Essandoh, O.K., Islam, M. and Kakinaka, M. (2020). Linking International Trade and Foreign Direct Investment to Co2 Emissions: Any Differences Between Developed and Developing Countries? Science of the Total Environment, 712 (2020) 136437. https://doi.org/10.1016/j. scitotenv.2019.136437 
18. Farhani, S., Shahbaz, M., and Arouri, M. E. H. (2013). Panel analysis of co2 emissions, gdp, energy consumption, trade openness and urbanization for Mena countries, MPRA Paper No. 49258.

19. Grossman, G.M. and Krueger, A.B. (1991). Environmental impacts of a North American free trade agreement. National Bureau of Economic Research, 3914, 1-57.

20. Grossman, G.M. and Krueger, A.B. (1995). Economic Growth and The Environment. The Quarterly Journal of Economics, 110(2), 353-377. https://doi.org/10.2307/2118443

21. Gul, E and Inal, V . (2017). Air Pollution and Economic Growth Relation: Time-Varying Panel Causality Analysis. The Sakarya Journal of Economics, 6 (2), 70-82.

22. Hoffmann, R., Lee, C., Ramasamy, B. and Yeung, M. (2005). Fdi and Pollution: A Granger Causality Test Using Panel Data. Journal of International Development, 17, 311-317. https://doi. org/10.1002/jid.1196

23. Huang, Y., Chen, X., Zhu, H., Huand, C. and Tian, Z. (2019). The Heterogeneous Effects of Fdi and Foreign Trade on Co2 Emissions: Evidence from China. Hindawi Mathematical Problems in Engineering, Article ID 9612492, https://doi.org/10.1155/2019/9612492.

24. Kasman, A. and Duman, Y.S. (2015). CO2 Emissions, Economic Growth, Energy Consumption, Trade and Urbanization in New EU Member and Candidate Countries: A Panel Data Analysis. Economic Modelling, 44, 97-103. https://doi.org/10.1016/j.econmod.2014.10.022

25. Kaya, G., Kayalica, M.O., Kumas, M. and Ulengin, B. (2017). The Role of Foreign Direct Investment and Trade on Carbon Emissions in Turkey. Environmental Economics, 8(1), 8-17. http://dx.doi.org/10.21511/ee.08(1).2017.01

26. Kuznets, S. (1955). Economic Growth and Income Inequality. The American Economic Review, $45(1), 1-28$.

27. Lee, J.W. (2013). The Contribution of Foreign Direct Investment to Clean Energy Use, Carbon Emissions and Economic Growth. Energy Policy, 55, 483-489. https://doi.org/10.1016/j. enpol.2012.12.039

28. Lv, Z. and Xu, T. (2019). Trade Openness, Urbanization and Co2 Emissions: Dynamic Panel Data Analysis of Middle-Income Countries. The Journal of International Trade \& Economic Development, 28 (3), 317-330. https://doi.org/10.1080/09638199.2018.1534878

29. Omisakin, O., Adeniyi, O. and Omojolaibi, A. (2009). Foreign Direct Investment, Trade Openness and Growth in Nigeria. Journal of Economics Theory, 3, 13-18.

30. Omri, A., Nguyen, D. K. and Rault, C. (2014). Causal Interactions Between Co2 Emissions, Fdi, and Economic Growth: Evidence From Dynamic Simultaneous-Equation Models. Economic Modelling, 42, 382- 389. https://doi.org/10.1016/j.econmod.2014.07.026

31. Pesaran, M.H. (2004). General Diagnostic Tests for Cross Section Dependence in Panels. IZA Discussion Paper No:1240, Institute of the Study of Labor, August 2004, Bonn, Germany.

32. Pesaran, M.H. (2007). A Simple Panel Unit Root Test in the Presence of Cross-Section Dependence, Journal of Applied Econometrics, 22, 265-312. https://doi.org/10.1002/jae.951

33. Pesaran, M.H. and Yamagata, T. (2008). Testing Slope Homogeneity in Large Panels. Journal of Econometrics, 142 (1), 50-93. https://doi.org/10.1016/j.jeconom.2007.05.010

34. Polat, M. (2018). The Impact of Foreign Direct Investment on The Firms in Stock Exchange and The Real Sector: Cointegration and Causality Analysis on Developing Countries. Bingol University Journal of Social Sciences Institute, 8 (16), 509-526.

35. Recepoglu, M., Doganay, M.A., and Deger, M. K. (2020). Relationships between Energy Consumption and Economic Growth: Panel Data Analysis on Provinces in Turkey (2004-2014). Dogus University Journal, 21 (1), 69-80.

36. Ren, S., Yuan, B., Ma, X. and Chen, X. (2014). International trade, FDI (foreign direct investment) and Embodied CO2 Emissions: A Case Study of Chinas Industrial Sectors. China Economic Review, 28, 123-134. https://doi.org/10.1016/j.chieco.2014.01.003

37. Sahin, D. and Durmus, S. (2019). Analysis of The Effect of Economic Growth and Environmetal Pollution On Health Expendtures in Oecd Countries. Finance, Politics \& Economic Reviews, 647, 185-201.

38. Salman, M., Long, X., Dauda, L., Mensah, C.N. and Muhammad, S. (2019). Different Impacts of Export and Import on Carbon Emissions Across 7 Asean Countries: A Panel Quantile Regression Approach. Science of the Total Environment, 686, 1019-1029. https://doi.org/10.1016/j. scitotenv.2019.06.019

39. Sbia, R., Shahbaz, M. and Hamdi, H. (2014). A Contribution of Foreign Direct Investment, Clean 
Energy, Trade Openness,Carbon Emissions and Economic Growth To Energy Demand in UAE. Economic Modelling, 36, 191-197. https://doi.org/10.1016/j.econmod.2013.09.047

40. Shahbaz, M., Nasreen, S. and Afza, T. (2011). Environmental Consequences of Economic Growth and Foreign Direct Investment: Evidence From Panel Data Analysis. MPRA Paper 32547, University Library of Munich, Germany.

41. Shahbaz, M., Tiwari, A.K. ve Nasir, M. (2013). The Effects of Financial Development, Economic Growth, Coal Consumption and Trade Openness on Co2 Emissions in South Africa. Energy Policy, 61, 1452-1459. https://doi.org/10.1016/j.enpol.2013.07.006

42. Shahbaz, M., Nasreen, S., Abbas, F. and Anis, O. (2015). Does Foreign Direct Investment Impede Environmental Quality in High, Middle And Low-Income Countries? Energy Economics, 51, 275287, doi: 10.1016/j.eneco.2015.06.01.

43. Shahbaz, M., Nasreen, S., Ahmed, K. and Hammoudeh, S. (2017). Trade Openness-Carbon Emissions Nexus: The Importance Of Turning Points of Trade Openness For Country Panels. Energy Economics, 61, 221-232.

44. Shahbaz, M., Gozgor, G., Adom, P.K. and Hammoudeh, S. (2019). The Technical Decomposition of Carbon Emissions and The Concerns About Fdi and Trade Openness Effects in the United States. International Economics, 159, 56-73. https://doi.org/10.1016/j.inteco.2019.05.001

45. Sun, C., Zhang, F. and Xu, M. (2017). Investigation of Pollution Haven Hypothesis For China: An Ardl Approach With Breakpoint Unit Root Tests. Journal of Cleaner Production, 161, 153-164. https://doi.org/10.1016/j.jclepro.2017.05.119

46. Stern, D. I. (2004). The Rise and Fall of The Environmental Kuznets Curve. World Development, 32(8): 1419-1439. https://doi.org/10.1016/j.worlddev.2004.03.004

47. Xu, Y.D. (2015). Foreign Direct Investment,Trade Openness and Co2 Emissions: Taking Shandong Province As An Example. Advanced Materials Research, 1073-1076 (2015), 2691-2699. https:// doi.org/10.4028/www.scientific.net/AMR.1073-1076.2691

48. Zhang, S., Liu, X. ve Bae, J. (2017). Does Trade Openness Affect Co2 Emissions: Evidence From Ten Newly Industrialized Countries? Environ Sci Pollut Res (2017) 24:17616-17625. DOI 10.1007/s11356-017-9392-8

49. Zubair, A.O., Samad, A.A. and Dankumo, A.M. (2020). Does Gross Domestic Income, Trade Integration, Fdi Inflows, Gdp, and Capital Reduces Co2 Emissions? An Empirical Evidence From Nigeria. Current Research in Environmental Sustainability, 2(2020): 100009. https://doi. org/10.1016/j.crsust.2020.100009 